\title{
The Fermentation of Lactulose by Colonic Bacteria
}

\author{
By SURINDER S. SAHOTA, PETER M. BRAMLEY ${ }^{1 *}$ AND \\ IAN S. MENZIES ${ }^{2}$ \\ ${ }^{1}$ Department of Biochemistry, Royal Holloway College, Egham, Surrey TW20 OEX, U.K. \\ ${ }^{2}$ Department of Chemical Pathology, St Thomas's Hospital Medical School, \\ London SE1 7EH, U.K.
}

(Received 26 March 1981; revised 13 May 1981)

\begin{abstract}
Sixty-four strains of intestinal bacteria were cultured under anaerobic conditions in lactulose-containing media to assess their ability to ferment lactulose. Some organisms were unable to metabolize the disaccharide, while others, e.g. clostridia and lactobacilli, metabolized lactulose extensively. Quantitative analyses of the fermentation products indicated that the major non-gaseous metabolites were acetic, lactic and butyric acids. Hydrogen and carbon dioxide were the only gases detected. Fermentation products were estimated for selected species throughout their growth cycles. The products of fermentation of lactulose by stool cultures varied with incubation conditions such as $\mathrm{pH}$, but correlated well with those produced by pure cultures. These results are discussed in relation to the therapeutic uses of lactulose.
\end{abstract}

\section{INTRODUCTION}

The synthetic disaccharide lactulose (4- $O-\beta$-D-galactopyranosyl $\mathrm{D}$-fructofuranose) cannot be hydrolysed by human intestinal $\beta$-galactosidases (EC 3.2.1.23; Dahlquist \& Gryboski, 1965; Udupihille, 1974) and, except for slow permeation of the intact disaccharide, is not absorbed from the small intestine (Müller et al., 1969; Carulli et al., 1972). Consequently, following ingestion it passes to the colon, where it undergoes rapid fermentation by the colonic flora (Hoffmann et al., 1964) to products which cause acidification of the stool contents and flatulence (Agostini et al., 1972). Ingestion of sufficient amounts of lactulose produces a diarrhoea that is both osmotic and fermentative.

Because of this resistance to intestinal hydrolases, lactulose is used clinically for the treatment of acute constipation (Wesselius-De Casparis et al., 1968) and portal systemic encephalopathy (e.g. Bircher et al., 1966; Simmons et al., 1970), and for the assessment of small bowel transit time (Bond \& Levitt, 1975).

Although the therapeutic uses of lactulose involve, or may be modified by, bacterial degradation within the intestine, there is little detailed knowledge of this process. The few reported investigations indicate that some Gram-positive cocci and bacilli metabolize lactulose (Hoffmann et al., 1964) as do several bacteroides (Ruttloff et al., 1967). The former workers showed that lactic acid is the principal end-product, but reported no quantitative data.

The present investigation was undertaken to extend knowledge of the fermentation of lactulose by individual types of intestinal micro-organisms. Utilization of lactulose and formation of fermentation products have been estimated quantitatively for 64 strains of bacteria, cultured anaerobically, the behaviour of selected species being assessed throughout their growth cycles. These data have been compared with the results of anaerobic fermentations of lactulose by cultures of mixed organisms from faecal homogenates. 


\section{METHODS}

Organisms. Strains of lactobacillus were purchased from the N.C.I.B., Torry Research Station, Aberdeen. All other organisms were kindly provided by Dr A. Vince, The Rayne Institute, University College Hospital Medical School, London; Dr M. Hill, Bacterial Metabolism Research Laboratory, Central Public Health Laboratory, London, and Professor I. Phillips, Department of Microbiology, St Thomas's Hospital Medical School, London.

Media and growth conditions. All organisms were maintained on Oxoid 'Cooked Meat' medium (CM349) and stored at $-70^{\circ} \mathrm{C}$, after the addition of glycerol to a final concentration of $15 \%(\mathrm{v} / \mathrm{v})$. The purity of the strains was verified at regular intervals after culturing on blood agar. A standard sugar-free basal liquid medium (Holdeman $e t$ al., 1977) was used, and when necessary, lactulose was added via a $0.22 \mu \mathrm{m}$ bacteriological filter, to a final concentration of $40 \mathrm{~mm}$.

Routine screening of the bacterial strains for their ability to utilize lactulose was carried out by inoculating ( $5 \%$, $\mathrm{v} / \mathrm{v})$ liquid media $(15 \mathrm{ml}$, with and without lactulose) with cultures which had been grown overnight in basal medium. They were then incubated at $37^{\circ} \mathrm{C}$ for $48 \mathrm{~h}$ in an atmosphere of $\mathrm{N}_{2} / \mathrm{H}_{2} / \mathrm{CO}_{2}(80: 10: 10$, by vol.). Time-course experiments over a $24 \mathrm{~h}$ period were conducted similarly, with sampling every $4 \mathrm{~h}$. Bacterial growth was measured turbidimetrically at $612 \mathrm{~nm}$, and $\mathrm{pH}$ was measured by a microelectrode. Culture supernatants were obtained by centrifugation at $2000 \mathrm{~g}$ for $15 \mathrm{~min}$.

Determination of carbohydrates. The carbohydrates in culture supernatants were separated by thin-layer chromatography on silica gel $G$ and subsequently quantified by locating and scanning the appropriate bands (Menzies et al., 1978). Alternatively, when lactulose was the only sugar present it was estimated by the method of Vachek (1971).

Determination of non-gaseous fermentation products. These were separated by gas chromatography (Pye-Unicam model 204, fitted with a flame ionization detector) on glass columns $(2 \mathrm{~m} \times 4.5 \mathrm{~mm}$, internal diameter) packed with Diatomite C (acid washed, 60-80 mesh) coated with 10\% polyethylene glycol 20M. The following conditions were employed: gas flow rates of 50,750 and $45 \mathrm{ml} \mathrm{min}^{-1}$ for $\mathrm{H}_{2}$, air and $\mathrm{N}_{2}$, respectively; injection port temperature $120^{\circ} \mathrm{C}$, detector temperature $180^{\circ} \mathrm{C}$ and a temperature programme of $8{ }^{\circ} \mathrm{C} \mathrm{min}{ }^{-1}$ from $60^{\circ} \mathrm{C}$ to $160^{\circ} \mathrm{C}$, the final temperature being maintained for $15 \mathrm{~min}$.

Quantification of non-gaseous products was achieved by comparing the integrated peak areas of standard compounds with those of experimental samples, using internal markers of butanol and malonic acid for volatile and non-volatile fatty acids, respectively.

In order to avoid losses due to evaporation, acetic and formic acids were determined directly on culture supernatants, using a standard test kit for acetic acid (Boehringer Corporation) and formate dehydrogenase (EC 1.2.1.2) for formic acid (Schutte et al., 1976).

The other non-gaseous products were extracted from acidified culture supernatants $(2.4 \mathrm{ml})$ containing the appropriate internal marker $(0.1 \mathrm{ml})$. Volatile fatty acids were obtained directly by partition with diethyl ether $(1.0 \mathrm{ml})$, while non-volatile fatty acids were methylated with $14 \%(\mathrm{v} / \mathrm{v})$ boron trifluoride in methanol $(2.5 \mathrm{ml})$ at room temperature, overnight, and then partitioned with chloroform $(1.25 \mathrm{ml})$. This methylation procedure gave recoveries of $93 \pm 2 \%$ for lactic acid.

Determination of gaseous fermentation products. These were initially detected and their total volumes estimated after collection in inverted sample tubes which had been placed in the media prior to inoculation. Qualitative analyses were then carried out by gas chromatography on glass columns $(1.5 \mathrm{~m} \times 4.5 \mathrm{~mm}$ i.d.) packed with silica gel (80-100 mesh; Phase Separations, Queensferry, Clywd). The following conditions were used: carrier gas $\left(\mathrm{N}_{2}\right)$ flow rate $50 \mathrm{ml} \mathrm{min}-1$; injection port temperature $50^{\circ} \mathrm{C}$; column temperature $50^{\circ} \mathrm{C}$; detector temperature $50^{\circ} \mathrm{C}$ and a bridge current of the catharometer of $95 \mathrm{~mA}$.

Selected bacteria were cultured, as described earlier, in gas-tight vials (Hypo-vials, Pierce and Warriner, Chester) under $\mathrm{N}_{2}$. Samples $(1 \mathrm{ml}$ ) were removed from the head space with a gas-tight syringe and injected on to the column. Retention times were compared with those of a standard gas mixture containing methane, ethane, propane and butane (Phase Separations) and also with hydrogen and carbon dioxide (British Oxygen, Wembley, Middlesex).

Incubation with mixed faecal organisms. These samples were kindly provided by Dr A. Vince. They were incubated anaerobically at $37^{\circ} \mathrm{C}$ for $48 \mathrm{~h}$ in the presence of $90 \mathrm{~mm}$-lactulose, as described elsewhere (Vince et al., 1978). After centrifugation at $47500 \mathrm{~g}$ for $90 \mathrm{~min}$ at $4{ }^{\circ} \mathrm{C}$ the supernatants were removed and analysed for fermentation products as described above.

\section{RESULTS}

\section{Utilization of lactulose}

The amount of lactulose fermented over a $48 \mathrm{~h}$ period varied significantly, not only from genus to genus but also, in some cases, between different strains of the same species (Table 1). 
Table 1. Utilization of lactulose $(40 \mathrm{~mm})$ by colonic bacteria

\begin{tabular}{|c|c|c|c|}
\hline & Organism* & $\begin{array}{l}\text { Percentage utilization } \\
\text { after } 48 \mathrm{~h} \text { cultivation }\end{array}$ & Gas production $\dagger$ \\
\hline $\begin{array}{l}\text { Organisms utilizing } \\
>20 \% \text { lactulose }\end{array}$ & $\begin{array}{l}\text { Bacteroides oralis } \ddagger \\
\text { Bacteroides vulgatus } \ddagger \\
\text { Bifidobacterium bifidum } \\
\text { Clostridium perfringens (8) } \\
\text { Lactobacillus casei } \text { sub. casei } \\
\text { Lactobacillus spp. (4) }\end{array}$ & $\begin{array}{l}21 \cdot 0 \\
21 \cdot 0 \\
30 \cdot 5 \\
33 \cdot 6-43 \cdot 1 \\
33 \cdot 5 \\
21 \cdot 1-47 \cdot 3\end{array}$ & $\begin{array}{r}- \\
+ \\
- \\
+ \\
- \\
-\end{array}$ \\
\hline $\begin{array}{l}\text { Organisms utilizing } \\
5-20 \% \text { lactulose }\end{array}$ & $\begin{array}{l}\text { Bacteroides distasonis } \ddagger \text { (3) } \\
\text { Bacteroides fragilis (6) } \\
\text { Bacteroides ovatus (2) } \\
\text { Bacteroides thetaiotaomicron (3) } \\
\text { Bacteroides uniformis (3) } \\
\text { Bacteroides vulgatus } \ddagger \\
\text { Clostridium butyricum (3) } \\
\text { Clostridium cadaveris (2) } \\
\text { Clostridium difficile (2) } \\
\text { Enterobacter aerogenes } \\
\text { Escherichia coli } \\
\text { Klebsiella aerogenes } \\
\text { Lactobacillus acidophilus }(2) \\
\text { Lactobacillus brevis } \\
\text { Peptostreptococcus anaerobius } \\
\text { Proteus mirabilis } \\
\text { Proteus vulgaris } \\
\text { Staphylococcus aureus } \\
\text { Streptococcus faecalis } \\
\text { Streptococcus intermedius } \\
\text { Streptococcus sp. } \\
\text { Streptococcus viridans }\end{array}$ & $\begin{array}{l}11 \cdot 5-19 \cdot 5 \\
9 \cdot 0-13 \cdot 5 \\
5 \cdot 0-8 \cdot 1 \\
5 \cdot 0-8 \cdot 0 \\
9 \cdot 4-13 \cdot 5 \\
9 \cdot 8 \\
7 \cdot 5-19 \cdot 0 \\
5 \cdot 0-17 \cdot 5 \\
5 \cdot 0-13 \cdot 8 \\
12 \cdot 0 \\
5 \cdot 0 \\
9 \cdot 6 \\
10 \cdot 0-13 \cdot 1 \\
13 \cdot 2 \\
10 \cdot 0 \\
11 \cdot 6 \\
16 \cdot 1 \\
7 \cdot 0 \\
6 \cdot 0 \\
6 \cdot 6 \\
8 \cdot 8 \\
6 \cdot 0\end{array}$ & $\begin{array}{l}- \\
+ \\
+ \\
+ \\
+ \\
+ \\
2+ \\
2+ \\
2+ \\
+ \\
+ \\
- \\
- \\
- \\
2+ \\
2+ \\
2+ \\
- \\
+ \\
+ \\
+ \\
+\end{array}$ \\
\hline
\end{tabular}

The following organisms were found to utilize $<5 \%$ of the added lactulose and no gaseous products were formed: Bacteroides mel assacharolyticus, Clostridium paraputrificum, Eubacterium lentum, Eubacterium limosum, Fusobacterium nucleatum, Lactobacillus buchneri, Neisseria catarrhalis, Propionibacterium acnes, Veillonella parvula.

\footnotetext{
* Number of strains shown in parentheses if more than one used.

+ Scored on a scale + to $3+$.

$\ddagger$ Galactose and/or fructose found in the culture medium after growth.
}

Some $14 \%$ of the 64 strains examined showed negligible $(<5 \%)$ utilization of lactulose, while the majority $(61 \%)$ of the organisms fermented an 'intermediate' (5-20\%) amount of the disaccharide. The latter group consisted of coliforms, bacteroides, streptococci and all but two species of clostridia. The culture supernatants of Bacteroides distasonis, B. oralis and $B$. vulgatus contained small quantities of galactose and fructose (Table 1).

Of the three organisms selected from those exhibiting over $20 \%$ utilization of lactulose, only Clostridium perfringens exhibited a typical growth pattern when cultured on 40 mm-lactulose (Fig. 1). Both Bacteroides vulgatus and the Lactobacillus sp. metabolized the majority of the disaccharide in the stationary phase, an example of deferred substrate utilization. In all three, the total quantities of lactulose utilized after $24 \mathrm{~h}$ were similar to those at the $48 \mathrm{~h}$ stage in the earlier screening experiment (Table 1). A fall in $\mathrm{pH}$ of 2.0-2.5 units was found over the $24 \mathrm{~h}$ fermentation (data not shown).

\section{Fermentation products}

In order to accurately quantify the products of lactulose fermentation, it was necessary to compare the types and amounts of the products after growth on basal medium and on lactulose-supplemented medium. 


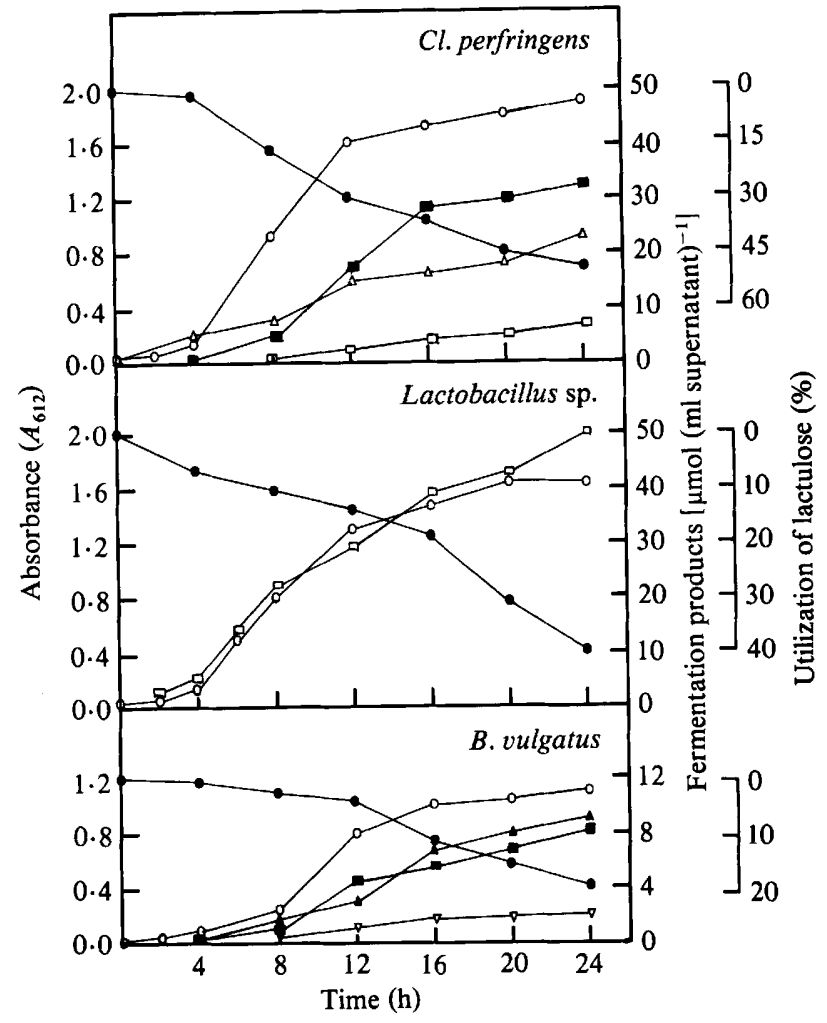

Fig. 1. Growth of selected organisms on $40 \mathrm{~mm}$-lactulose. Absorbance (O), utilization of lactulose (O), concentrations of fermentation products - lactic acid $(\square)$, acetic acid $(\boldsymbol{\square})$, butyric acid $(\triangle)$, succinic acid $(\Delta)$, propionic acid $(\nabla)$.

\section{Table 2. Quantitative analysis of significant non-gaseous products of lactulose fermentation}

The values quoted show the increment in the fermentation product observed with the strains employed.

\begin{tabular}{|c|c|c|c|c|c|}
\hline \multirow[b]{2}{*}{ Organism* } & \multicolumn{5}{|c|}{ Product $\left[\mu \mathrm{mol}(\mathrm{ml} \text { culture supernatant })^{-1}\right]$} \\
\hline & $\begin{array}{l}\text { Acetic } \\
\text { acid }\end{array}$ & $\begin{array}{c}\text { Butyric } \\
\text { acid }\end{array}$ & $\begin{array}{c}\text { Isovaleric } \\
\text { acid }\end{array}$ & $\begin{array}{l}\text { Lactic } \\
\text { acid }\end{array}$ & $\begin{array}{l}\text { Succinic } \\
\text { acid }\end{array}$ \\
\hline B. fragilis (6) & $3 \cdot 2-8 \cdot 9$ & - & - & $3 \cdot 9-7 \cdot 25$ & $2 \cdot 1-4 \cdot 1$ \\
\hline Cl. perfringens (8) & $7 \cdot 3-11 \cdot 3$ & $14 \cdot 05-25 \cdot 4$ & - & $3 \cdot 2-15 \cdot 4$ & - \\
\hline E. coli & 3.8 & - & - & 2.75 & - \\
\hline L. acidophilus & - & - & - & $21 \cdot 2$ & - \\
\hline P. anaerobius & 1.9 & - & 1.00 & - & - \\
\hline St.faecalis & $4 \cdot 5$ & - & 0.7 & $3 \cdot 0$ & - \\
\hline
\end{tabular}

* Number of strains shown in parentheses if more than one used.

Both qualitative and quantitative differences were found on addition of $40 \mathrm{~mm}$-lactulose to the medium. Generally, large increases in acetic, lactic and butyric acids were found, with butyric acid being a characteristic product of clostridia. Bacteroides predominantly metabolized lactulose to acetic and succinic acids, but produced smaller quantities of higher fatty acids during lactulose fermentation than with basal medium alone. The lactobacilli exhibited a homolactic fermentation pattern. Formic acid was not detected by either enzymic or gas-liquid chromatographic analyses. Quantitative analyses of the non-gaseous fermentation products of representative species are shown in Table 2. 
Table 3. Non-gaseous products of in vitro incubation of $90 \mathrm{mM}$-lactulose with faecal homogenates

Each value is the mean of duplicate incubations.

Incubation condition

+ Lactulose,

$\mathrm{Oh}$

+ Lactulose,

$48 \mathrm{~h}$

+ Lactulose,

$48 \mathrm{~h}$, titrated

to $\mathrm{pH} \geqslant 5 \cdot 5$

Product* $\left[\mu \mathrm{mol}(\mathrm{ml} \text { culture supernatant })^{-1}\right]$

$\begin{array}{rrrrrrrrrrr}\text { Ac } & \text { Prop } & \text { iBut } & \text { But } & \text { iVal } & \text { Val } & \text { Cap } & \text { iCap } & \text { Lac } & \text { Fum } & \text { Succ } \\ 19.9 & 2.4 & 0.3 & 2.8 & 0.4 & 0.4 & 0.4 & 0.4 & 0.0 & 0.0 & 0.0 \\ 116.7 & 9.5 & 0.3 & 29.8 & 0.4 & 0.5 & 0.6 & 0.2 & 52.6 & 0.0 & 0.0 \\ 99.1 & 17.2 & 1.7 & 65.5 & 1.7 & 3.4 & 9.3 & 0.4 & 0.0 & 2.3 & 3.6\end{array}$

* Ac, acetic acid; Prop, propionic acid; iBut, isobutyric acid; But, butyric acid; iVal, isovaleric acid; Val, valeric acid; Cap, caproic acid; iCap, isocaproic acid; Lac, lactic acid; Fum, fumaric acid; Succ, succinic acid.

Of those organisms utilizing more than $5 \%$ of the available lactulose, some $63 \%$ produced gases during fermentation, with strains of $\mathrm{Cl}$. perfringens evolving the largest quantities (Table 1). Carbon dioxide and hydrogen were the only gases detected in these cases, methane being absent.

Analyses of fermentation products throughout growth of the three selected bacteria showed that all the metabolites were excreted during each phase of growth (Fig. 1).

\section{Incubations with faecal homogenates}

The fermentation products of the mixed cultures from faecal homogenates, incubated with lactulose, differed depending on the condition of the incubations (Table 3). Untitrated incubations over a $48 \mathrm{~h}$ period showed large increases in acetic, butyric and lactic acids, but maintenance of $\mathrm{pH} \geqslant 5.5$ inhibited lactic acid formation while the production of butyric, succinic and longer-chain fatty acids was elevated under these conditions.

\section{DISCUSSION}

The amounts of lactulose fermented by the 64 strains of gut bacteria (Table 1) indicate that of the three quantitatively predominant gut genera (all approx. $10^{10}$ per $\mathrm{g}$ faeces; Drasar \& Hill, 1974), eubacteria do not play a significant role in colonic lactulose metabolism, whereas strains of both bacteroides and bifidobacteria show high amounts of lactulose utilization in vitro (Table 1). Other quantitatively important colonic organisms such as streptococci and enterobacteria (both approx. $10^{8}$ per $\mathrm{g}$ faeces) exhibit a rather low ability to use lactulose (5-10\%, Table 1). Although both lactobacilli and clostridia do not occur in such high numbers in the lower intestine $\left(10^{5}-10^{6}\right.$ per $\mathrm{g}$ faeces), the large amount of lactulose utilized by certain strains (Table 1), the extent of which was confirmed by their comparatively high rates of uptake during exponential and stationary phases of growth (Fig. 1), suggests that such organisms are important in the metabolism of lactulose in the colon.

The non-gaseous fermentation products of lactulose (Table 2) were qualitatively the same as those obtained when these organisms were cultured on glucose (Holdeman et al., 1977), suggesting that similar glycolytic pathways are operative for both carbohydrates. This is the first report of butyric acid formation from lactulose and indicates that the mixture of fermentation products present in the colon during lactulose therapy is more complex than has been claimed previously (Conn \& Lieberthal, 1979). These organisms are also able to utilize the aldose isomer lactose (Holdeman et al., 1977), suggesting that prokaryotes are relatively non-specific with respect to $\beta$-D-galactoside metabolism, in contrast to human intestinal $\beta$-galactosidases (Dahlquist \& Gryboski, 1965). 
The formation of carbon dioxide and hydrogen during growth on lactulose (Table 1) correlates with the characteristic flatulence experienced after ingesting therapeutic doses of lactulose (Elkington, 1970). The evolution of hydrogen forms the rationale of tests for sugar absorption and intestinal transit time based on the appearance of this gas in expired air when a non-absorbed sugar, such as lactulose, enters the lower intestine (Bond \& Levitt, 1975; Metz et al., 1975, 1976).

Mixed populations of bacteria, derived from faecal homogenates and incubated with lactulose, generated increased amounts of acetic, lactic and butyric acids in the same way that occurred when individual organisms were cultured (Table 3 ) and is probably due to the activity of acid-tolerant lactobacilli, streptococci and clostridia. Viable cell counts of streptococci and clostridia do not alter significantly over $48 \mathrm{~h}$ in untitrated incubations, but bacteroides decrease markedly over the same period (Vince et al., 1978). It is significant, therefore, that on maintenance of a $\mathrm{pH} \geqslant 5.5$ during incubation, the balance of fermentation products is altered in favour of succinic and higher fatty acids, presumably because bacteroides and other acid-sensitive organisms were metabolically more active at such $\mathrm{pH}$ values. Since high oral doses of lactulose, as used in the treatment of hepatic coma, produce acidification of colonic contents to below pH 5.5 (Conn \& Lieberthal, 1979), acetic, butyric and lactic acids may become the predominant metabolic products in the colon.

The mode of action of lactulose in the alleviation of hepatic coma is still unclear (Conn \& Lieberthal, 1979). However, blood ammonia levels, a major aetiological factor in this condition, do fall significantly during lactulose therapy (Conn et al., 1977). Since significant quantitative changes in the gut flora of adults do not appear to be induced by oral lactulose administration (Vince et al., 1974), a current hypothesis to explain this phenomenon is that lactulose fermentation in the colon enables certain unspecified organisms to increase the rate of incorporation of colonic ammonia into bacterial proteins (Vince et al., 1978). Such investigations would be assisted by more detailed knowledge of bacterial interactions occurring in the colon, and also of the selective toxicity to bacterial species of fermentation products (Bergeim, 1940; Lee \& Gemmell, 1971). Our present studies, which detail the products of lactulose metabolism and show which colonic organisms are capable of growth on lactulose, should facilitate future work on this complex subject.

We wish to thank Professor I. Phillips, Dr A. Vince and Dr M. Hill for supplying the organisms and Ms L. Taylor for identifying them. We also thank Philips-Duphar B.V., Weesp, Holland, for supplying crystalline lactulose. S.S.S. was in receipt of a SRC/CASE studentship in conjunction with Duphar Laboratories Ltd, Southampton.

\section{REFERENCES}

Agostini, L., Down, P. F., Murison, J. \& Wrong, O. M. (1972). Faecal ammonia and pH during lactulose administration in man: comparison with other cathartics. Gut 13, 859-866.

BERGEIM, O. (1940). Toxicity of intestinal volatile fatty acids for yeast and Escherichia coli. Journal of Infectious Diseases 66, 222-234.

Bircher, J., Müller, J., Guggenheim, P. \& Haemmerli, U. P. (1966). Treatment of chronic portal-systemic encephalopathy with lactulose. Lancet 1, 890-893.

BoND, J. H., JR \& LEVITT, M. D. (1975). Investigation of small bowel transit time in man utilising pulmonary hydrogen $\left(\mathrm{H}_{2}\right)$ measurements. Journal of Laboratory and Clinical Medicine 85, 546-555.

Carulli, J., Salvioli, G. F. \& Manenti, F. (1972), Absorption of lactulose in man. Digestion 6, 139-145.

Conn, H. O. \& Lieberthal, M. M. (1979). The
Hepatic Coma Syndromes and Lactulose. Baltimore: Williams \& Wilkins.

ConN, H. O., Leevy, C. M., Vlahcevic, Z. R., Rodgers, J. B., Maddrey, W. C., Seef, L. \& LEVY, L. L. (1977). Comparison of lactulose and neomycin in the treatment of chronic portal-systemic encephalopathy. Gastroenterology 72, 573-583.

DAHLQUIST, A. \& GRYBoskI, I. (1965). Inability of the human small intestine to hydrolyse lactulose. Biochimica et biophysica acta 110, 635-636.

Drasar, B. S. \& HiLl, M. J. (1974). Human Intestinal Flora. London: Academic Press.

Elkington, S. G. (1970). Lactulose. Gut 11, 10431048.

Hoffmann, K., Mossel, D. A., Korus, W. \& van DE KAMER, J. H. (1964). Untersuchungen über die Wirkungsweise der Lactulose im Darm. Klinische Wochenschrift 42, 126-130.

Holdeman, L. V., Cato, E: P. \& Moore, W. E. C. 
(editors) (1977). Anaerobe Laboratory Manual, 4th edn. Blacksburg, Virginia, U.S.A.: V.P.I. Anaerobe Laboratory.

LeE, M. \& Gemmell, E. (1971). Changes in the mouse intestinal microflora during weaning: role of volatile fatty acids. Infection and Immunity 5, 1-7.

Menzies, I. S., Mount, J. N. \& Wheeler, M. J. (1978). Quantitative estimation of clinically important monosaccharides in plasma by rapid thin-layer chromatography. Annals of Clinical Biochemistry $15,65-76$.

Metz, G., Jenkins, D. J. A., Peters, T. J., Newman, A. \& BLENDIS, L. M. (1975). Breath hydrogen as a diagnostic method for hypolactasia. Lancet 1 , 1155-1157.

Metz, G., Jenkins, D. J. A., Newman, A., Blendis, L. M. (1976). Breath hydrogen in hyposucrasia. Lancet 1, 119-120.

Müller, M., Walker-Smith, J., Smerling, D. H., Curtius, H.-C. \& Prader, A. (1969). Lactulose: a gas-liquid chromatography method of determination and evaluation of its use to assess intestinal mucosal damage. Clinica chimica acta 24, 45-49.

Ruttloff, H., TÄufel, A., Haenel, H. \& TÄufel, K. (1967). Die intestinal-enzymatische Spaltung von Galakto-oligosacchariden im Darm von Tier und Mensch mit besonderer Berücksichtigung von Lactobacillus bifidus. 3: Mitt. Carbohydratische
Aktivität ausgewählter Mikroorganismen der Darmflora. Nährung 11, 47-54.

Schutte, H., Flossdorf, J., Sahm, H. \& Kula, M.-R. (1976). Purification and properties of formaldehyde dehydrogenase and formate dehydrogenase from Candida boidinii. European Journal of Biochemistry 62, 151-160.

Simmons, F., Goldstein, H. \& Boyle, J. D. (1970). A controlled clinical trial of lactulose in hepatic encephalopathy. Gastroenterology 59, 827-832.

UdUPIHILLE, M. (1974). Factors affecting human intestinal permeability of non-metabolized oligosaccharides. M.Phil., University of London.

VACHEK, J. (1971). Spectrophotometric determination of lactulose. Ceskoslovenská farmacie 20, 96-98.

Vince, A., ZEEgen, R., DRINKWATER, J. E., O'Grady, F. \& Dawson, A. M. (1974). The effect of lactulose on the faecal flora of patients with hepatic encephalopathy. Journal of Medical Microbiology 7, 163-168.

Vince, A., Killingley, M. \& Wrong, O. M. (1978). Effect of lactulose on ammonia production in a faecal incubation system. Gastroenterology 74, 544-549.

Wesselius-de Casparis, A., BraAdbaart, S., vd Bergh-Bohlken, G. E. \& MimicA, M. (1968). Treatment of chronic constipation with lactulose syrup: results of a double-blind study. Gut 9, 84-86. 